\title{
Implementation of a frequency control in a biomass gasifier system
}

\author{
Yecid Muñoz ${ }^{1}$, Adalberto Ospino ${ }^{2}$, Carlos Robles ${ }^{3}$, Carlos Arizmendi $^{4}$ \\ ${ }^{1,4}$ Facultad de Ingeniería, Universidad Autónoma de Bucaramanga, Colombia \\ ${ }^{2}$ Facultad de Ingeniería, Universidad de la Costa, Colombia \\ ${ }^{3}$ Facultad de Ingeniería, Universidad del Magdalena, Colombia
}

\begin{tabular}{l}
\hline Article Info \\
\hline Article history: \\
Received Feb 6, 2018 \\
Revised Aug 10, 2018 \\
Accepted Oct 8, 2018 \\
\hline
\end{tabular}

Keyword:

Biomass

Downdraft Gasifier

Microgrid

\begin{abstract}
Distributed power generation has grown in popularity in recent years, especially in areas not connected to the national grid. As a result, rural microgrids are becoming more common, involving great potential for energy based on biomass conversion such as gasification. After analyzing distributed power generation facilities in developing countries, the authors found problems with the frequency stability. This paper focuses on solving the problem of frequency control in energy supplied by microgrids based in biomass gasification. For that purpose, the authors have developed a physical model of a downdraft gasifier, this model was used for design a novel strategy for frequency control, which has been based and validated on an existing gasification system, which supplies power to a population in Necoclí (Colombia).
\end{abstract}

Copyright $(2019$ Institute of Advanced Engineering and Science. All rights reserved.

\section{Corresponding Author:}

Adalberto Ospino,

Facultad de Ingeniería,

Universidad de la Costa,

Calle 58 No 55-66, Barranquilla, Atlántico, Colombia.

Email: aospino8@cuc.edu.co

\section{INTRODUCTION}

The concept of distributed power generation (DG), or microgrids that work in isolation, is currently becoming an option to solve the problem of electricity supply, especially in rural areas in developing countries where the main grid is unavailable [1]-[4]. DG involves improvements in voltage profiles and reduces distribution losses because the generators are located near the rural load centers [5], [6].

The feasibility of biomass gasification in the rural electrification of remote areas has been widely investigated [7]. In [8] are considered different circumstances using an annual cost model taking into account the time-value of money, and suggests gasifier mass production as a prerequisite for making this technique feasible. Technology is currently closer to fulfilling this prerequisite and considering the rising price of fossil fuels and electricity, gasification is more applicable. Other authors present rural electrification as a favorable scenario for the gasification of biomass [9]. Biomass has a high potential contribution to the renewable energy mix in developing countries [10]-[12]. In the case of India, biomass-based power is widely available and more uniformly distributed than other renewable energy sources [13]. The potential for generation through renewable sources in India is $85 \mathrm{GW}$ and biomass could supply approximately $25 \%$ (about 20GW) and so represent a highly viable solution for the energy demands of small villages [14].

As in conventional grids, to maintain quality levels the frequency of the electricity must be maintained within a minimum deviation when using DG [15]. The authors in [16] suggest that DG units must contribute to frequency control and in order to contribute to primary frequency control these units must increase their power output. Various studies present simulations using the model of a conventional power 
plant [17], [18], wind turbine [19], micro-turbine [20], fuel cells [21] and spark ignition engine power system [22].

The Universidad Politécnica de Valencia (UPV) and the Instituto de Planificación de Soluciones Energéticas de Colombia (IPSE) examined biomass generation systems in rural off-grid areas of Colombia. They found serious power problems in the frequency stability of the network, with variations greater than $\pm 10 \%$ of the desired frequency of $60 \mathrm{~Hz}$. These problems are mostly caused by the lack of automation of the grid frequency control in biomass units.

To solve this problem, this paper firstly proposes a physical model of the dynamic behavior of an isolated downdraft biomass gasification system which will be used to design a cascade control system. This model is based and validated on an existing gasification system in Necoclí (Colombia). A global analysis has been made. Results from other authors, experimental data, and new contributions have been used to develop the physical modelling. This modelling takes into account the nonlinearities of the analyzed systems.

\section{SYSTEM PHYSICAL DESCRIPTION}

The physical system consists of a three-phase synchronous generator driven by a reciprocating internal combustion engine (RICE) powered by synthesis gas provided by a downdraft biomass gasifier. Figure 1 and Table 1 shows images of the system and gasifier specifications respectively.
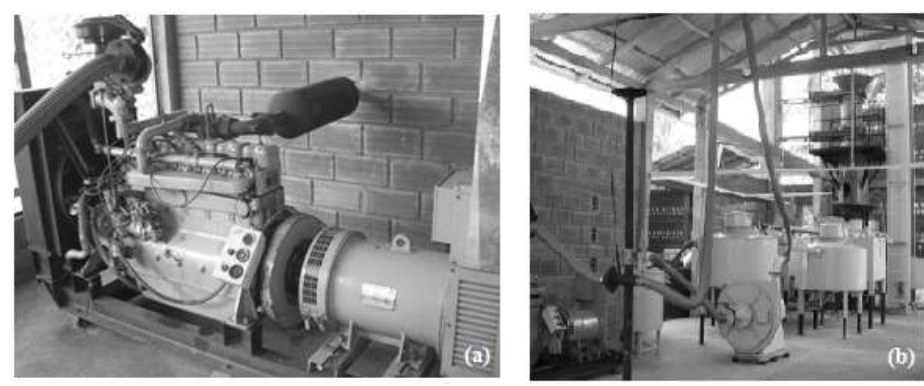

Figure 1. RICE-generator (a) and (b) Gasifier installed in Necoclí (Colombia)

A schematic diagram of the system is shown in Figure 2, which also identifies the components. The biomass is stored in the hopper and fed to the gasifier through the double door feeder system. A limited amount of air for partial combustion enters through the air valve to the combustion zone to ensure the production of a relatively clean and good quality gas.

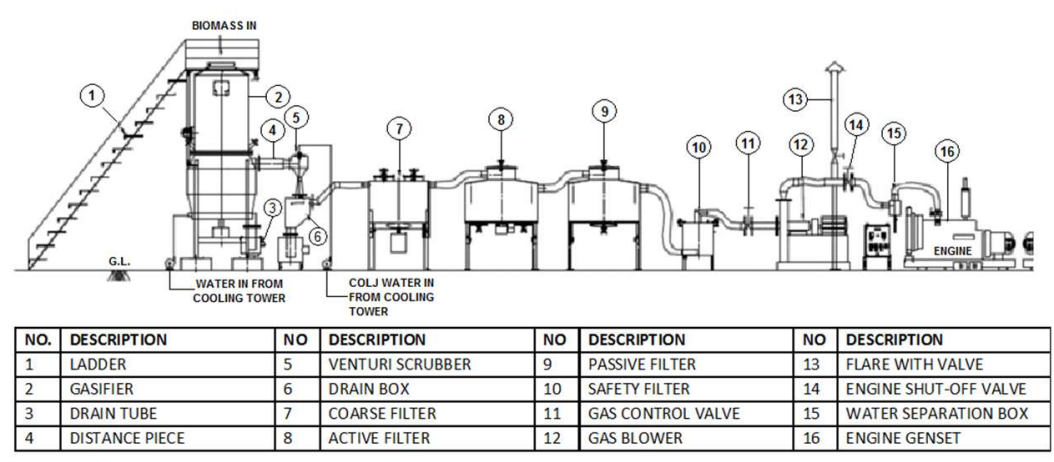

Figure 2. System layout

The reactor maintains a coal bed that enables the reduction (or gasification) of the partially burnt products, and facilitates the evacuation of ashes through a perforated wall (pushed into the ash collection chamber when necessary). The gas outlet is connected to the power plant through a Venturi Scrubber, followed by coarse filters, fine filters, and a security filter. These filters are then followed by a security flame and the output valve of the plant (for gas cleaning and operation). 
After the output of the gasifier, the synthesis gas (hereinafter, gas) generated by the gasification system, passes through a gas flow control valve (item 11 in Figure 2) and is sucked into the blower (item 12 in Figure 2). Finally, the gas goes through the engine valve to access an internal combustion engine coupled to the generator. In the case of the gasifier under consideration, air enters through the air nozzle of the hopper, and the amount entering the generator depends on the blower speed and the gas flow control valve. Specifications of the blower and RICE-generator are presented in Table 2.

Table 1. Gasifier Specifications

\begin{tabular}{ll}
\hline Characteristic & Value \\
\hline Model & Ankur WBG- 80 \\
Operating mode & Clean and cold gas \\
Electrical power & $40 \mathrm{~kW}$ \\
Gasifier type & Downdraft \\
Gasification temperature & $1050-1100^{\circ} \mathrm{C}$ \\
Gas flow & $200 \mathrm{~m} 3 / \mathrm{h}$ \\
Average calorific value & $1000 \mathrm{kcal} / \mathrm{m} 3$ \\
Cooling and cleaning system & Venturi Scrubber, fat filters, fine filters and safety filter \\
Start & Through the boot scrubber pump and blower \\
Fuel type and size & Waste wood with maximum dimensions: diameter $25-50$ mm and length $50-60 \mathrm{~mm}$ \\
Fuel consumption & $1.3-1.4 \mathrm{~kg} / \mathrm{kW}$. Wood containing less than $20 \%$ humidity \\
Allowed moisture & $5-20 \%$ \\
Nominal consumption per hour & $60-65 \mathrm{~kg} / \mathrm{h}$ \\
Ash discharge & $5-6 \%$ \\
Normal efficiency conversion & $>75 \%$ \\
Normal gas composition & $\mathrm{N} 2: 50 \%, \mathrm{CO}: 19 \pm 3 \%, \mathrm{H} 2: 18 \pm 2 \%, \mathrm{CO} 2: 10 \pm 3 \%, \mathrm{CH} 4:<3 \%$ \\
\hline
\end{tabular}

The energy generated by the plant (engine-generator) depends on the calorific value and gas flow entering and these parameters are a function of the air entering the process in the gasifier [23]. A physical analysis of the performance of each of the parts of the system is performed in this paper to determine the frequency supplied by the generator. To develop the proposed model of the system, the authors use existing models, simulations, and experimental values.

Table 2. Blower and RICE-Generator Specifications

\begin{tabular}{ccc}
\hline & Characteristic & Value \\
\hline Blower & Manufacturer & United Eng. Works \\
& Power (HP) & 3.0 \\
& Speed (rpm) & 3360 \\
& Voltage (V) & 215 \\
& Static pressure (mmwc) & 700 \\
Generation Plant & Flow (Nm3/h) & 300 \\
& Manufacturer & Prakash \\
& Model & PN-6 \\
& Power (HP) & 65 \\
Alternator & Speed (rpm) & 1,800 \\
& Manufacturer & Kirloskar \\
& Power (kVA) & 55 \\
& Voltage (V) & 220 \\
& Current (A) & 145 \\
& Speed (rpm) & 1800 \\
& Phases & 3 \\
\hline
\end{tabular}

\section{MATERIALS AND METHODS}

The methodology used to perform the global physical modelling of the system and implement the frequency control architecture is shown in Figure 3. The first step of the proposed methodology consists in a physical modelling of the whole system. The main parts of the system are: the gasifier (the model considers static and dynamic behavior), the blower (controls the gas flow), and the RICE-generator set. Secondly, validation of the model is performed in open loop using measurements obtained from the real system. A cascade control loop is proposed to develop frequency control using the model obtained in the previous steps. Finally, results are presented. 


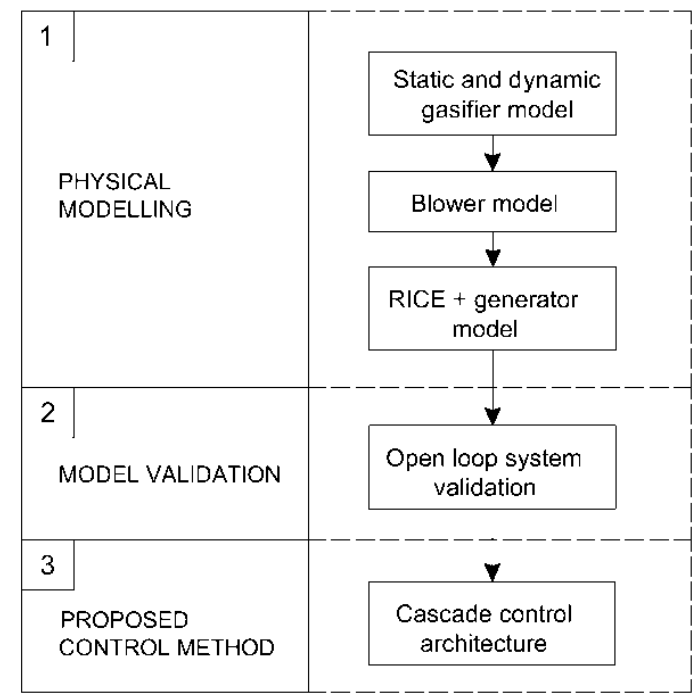

Figure 3. Methodology

\subsection{Downdraft gasifier physical modelling}

Gasification is a high-temperature thermo-chemical process that converts solid or liquid fuel into a gaseous fuel. This technique has been known for centuries, and has been used to obtain a cleaner and versatile fuel from unsuitable primary fuels. Gasifiers may be classified into two groups: fluid and fixed bed. Two types of fixed bed gasifiers exist according to the direction of movement of the biomass and gases: the counter-flow or updraft, and parallel-flow or downdraft. Downdraft is the most widely used technique, because it produces a cleaner gas than the other technique, despite having a lower thermodynamic efficiency [24], [25]. The physical and chemical processes that a solid fuel particle undergoes during gasification are [26]-[29]:

1. Drying: the process by which solid fuel loses humidity.

2. Primary pyrolysis: this process is fuel thermal decomposition, releasing gases such as $\mathrm{CO}, \mathrm{CO} 2, \mathrm{H} 2 \mathrm{O}$, H2, CH4 and many hydrocarbons, some of which have long chains called tars. The carbonaceous solid residue is carbon. This process has a complicated energy balance, being slightly endothermic or exothermic depending on the nature of the fuel.

3. Secondary pyrolysis: if temperature conditions permit, the released tars are burnt by an endothermic process that releases $\mathrm{CO}, \mathrm{CO} 2, \mathrm{H} 2 \mathrm{O}, \mathrm{H} 2, \mathrm{CH} 4$ and forms particles of coke.

4. Reactions of gases: if oxygen is present and the temperature is suitable, there is a combustion of gases released during the primary and secondary burnings. In addition, reduction or methanation reactions can occur-depending on the temperature.

5. Coal reactions: residual coal from the above reactions is burnt in the presence of oxygen releasing $\mathrm{CO}$ and $\mathrm{CO} 2$. $\mathrm{CO} 2$ reduction to $\mathrm{CO}$ and $\mathrm{CH} 4$ formation from $\mathrm{H} 2$ occurs if the temperature is appropriate.

Different areas may be defined in a downdraft gasifier in which the above described reactions take place as shown in Figure 4. These areas are distinguished by temperature. The quality of the gas produced by a downdraft gasifier may be predicted by numerical models and by estimating the chemical reactions using the theory of chemical kinetics [28], or with experimental values [23]-[30]. This paper takes into account the dynamic behavior of the gasifier.

Usually in the literature, the experimental values of the studied gasifiers are given in average values for periods of minutes for different ranges of stoichiometric combustion or ER (ER is the stoichiometric ratio of air needed to produce the complete combustion of wood, where ER=1 this corresponds to $5.22 \mathrm{Nm}^{3} / \mathrm{kg}^{\circ}$ of wood) [23]. In this work, the gas calorific value ( $\mathrm{HHV}$, expressed in $\mathrm{KJ} / \mathrm{Nm}^{3}$ ) for the gasifier studied is calculated according to the inflow of air (ma, expressed in $\mathrm{Nm}^{3} / \mathrm{h}$ ) by (1):

$$
H H V(m a)=0.5 e^{-\left(\frac{m a-1.3}{0.22}\right)^{2}}+1.6 e^{-\left(\frac{m a-1.07}{0.13}\right)^{2}}+4.8\left(1-e^{-6(m a-0.5)}\right)
$$

Where $0.87<\mathrm{ma}<1.89$. Figure 5 shows the experimental values and those obtained through (1). Figure 6 shows the implementation carried out in Matlab-Simulink to obtain HHV. 


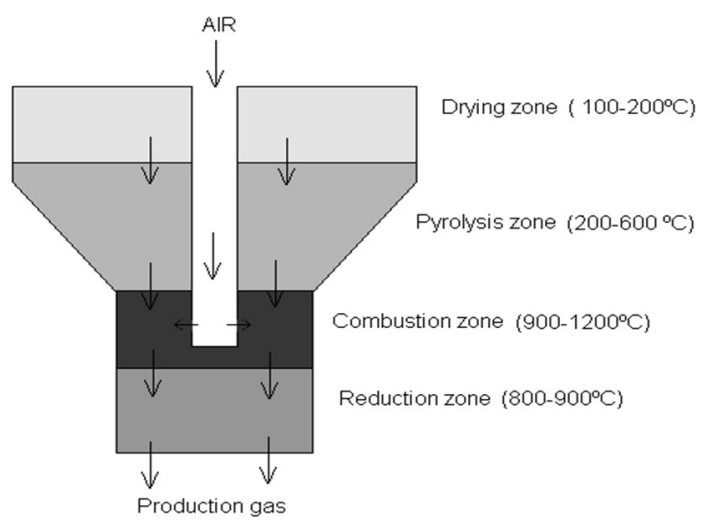

Figure 4. Areas of a downdraft gasifier

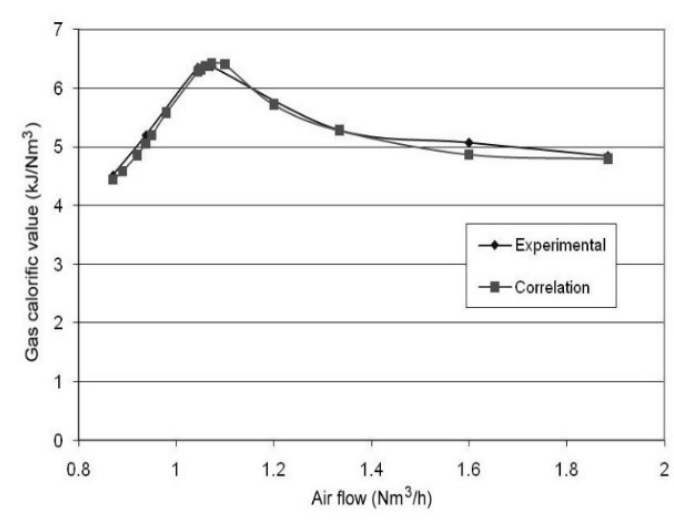

Figure 5. Calorific value of gas (HHV)

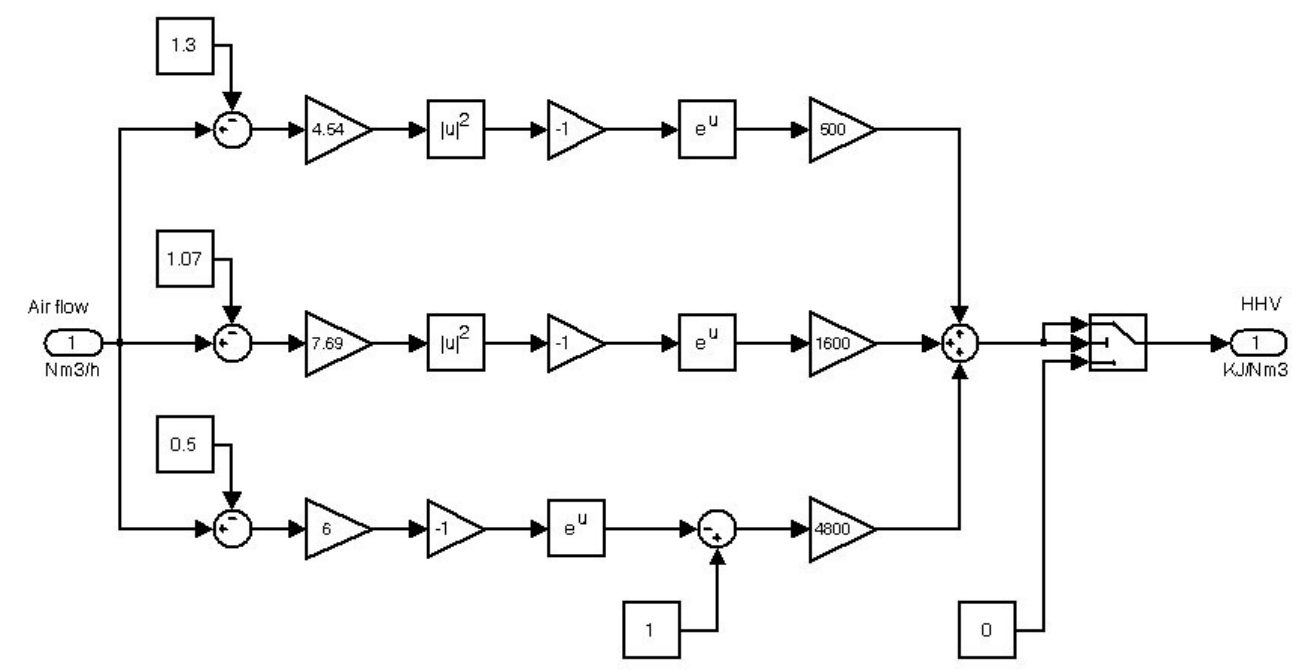

Figure 6. Matlab-Simulink block diagram

Furthermore, gas flow (mg expressed in $\mathrm{Nm} 3 / \mathrm{h}$ ) produced by air flow during gasification is shown in Figure 7 for the analyzed gasifier [30], [31]. The produced gas flow can then be estimated in a linear correlation (2)

$$
m g(t)=1.2664 m a(t)+0.137
$$

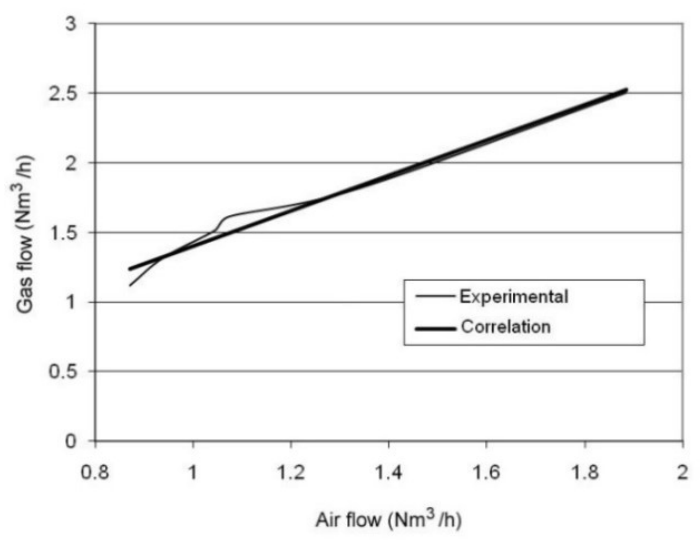

Figure 7. Gas flow versus air flow for the analyzed gasifier 
Finally, gas thermal power $(\mathrm{P}(\mathrm{t})$ expressed in $\mathrm{KW})$ is given by the product of $(1)$ and $(2)$ and a factor of 0.278 to express $\mathrm{kJ} / \mathrm{h}$ into $\mathrm{kW}$. (3)

$$
P(t)=0.278 H H V(t) m g(t)
$$

\subsection{Blower model}

Electrical frequency directly depends on the blower, since variations of engine speed directly influence the gas flow entering the RICE and the calorific value of the gas supplied by the gasifier. Real tests of the dynamic response of a downdraft gasifier have been performed in the laboratories of the Institute for Energy Engineering at the UPV. The objective was to model air flow depending on blower speed, by measuring the inlet flow with a hot wire flow-meter. The control variable is the speed of the induction engine that drives the blower and the air flow at the input of the blower. The transfer function for the airflow value following a frequency change in the nominal operating point of the gasifier was obtained experimentally (4).

$$
G m a(s)=\frac{0.9616}{s^{2}+0.5236 s \quad .8742}\left[\mathrm{Nm}^{3} / \mathrm{hHz}\right]
$$

The experimental response and the simulated response generated using Matlab-Simulink block for a $10 \mathrm{~Hz}$ step input are shown in Figure 8.

\subsection{RICE-generator physical modeling}

The dynamic behavior of the rotational speed of an alternative internal combustion engine (RICE) depends of four variables: the calorific value of the fuel, the air flow, the load to be supplied by the engine and the spark advance. The engine may be controlled by changing the flow of fuel, and as shown in the previous section, this varies the composition of the gas obtained in the gasifier. To analyze the behavior of a RICE when changing the fuel supply, the aspects discussed in the following sections must be considered. The engine response at different speeds and different power levels depending on fuel consumption is given by the lines of Willans as shown in Figure 9.

As shown in Figure 9, a linear increase of fuel consumption is produced when increasing the supplied power for a given engine speed. Since all lines have the same slope it can be stated that the final value of the fuel consumption is directly proportional to the force obtained, therefore:

1. The engine slows when it receives an increase in load for a given fuel consumption.

2. In a steady state of load and speed, it is possible to increase fuel consumption to recover initial velocity.

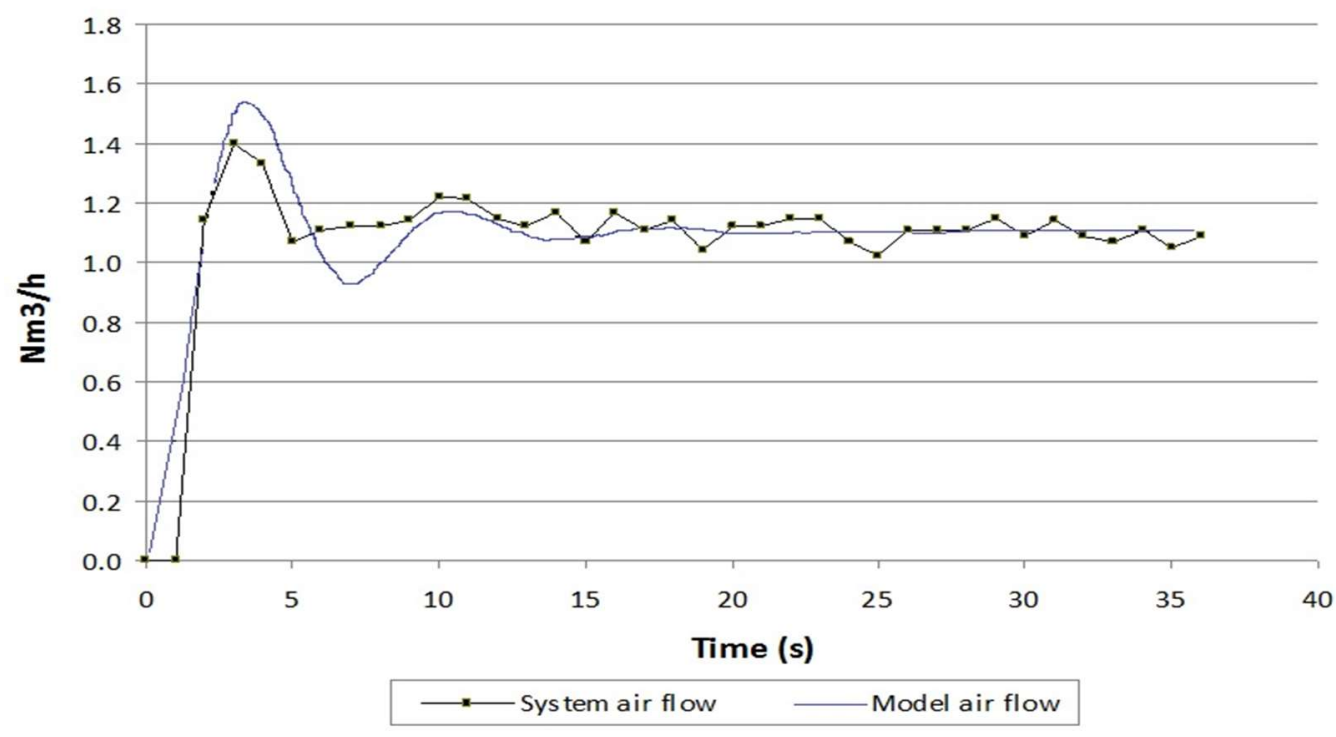

Figure 8. Gas flow obtained for a $10 \mathrm{~Hz}$ step input in the frequency of the blower 


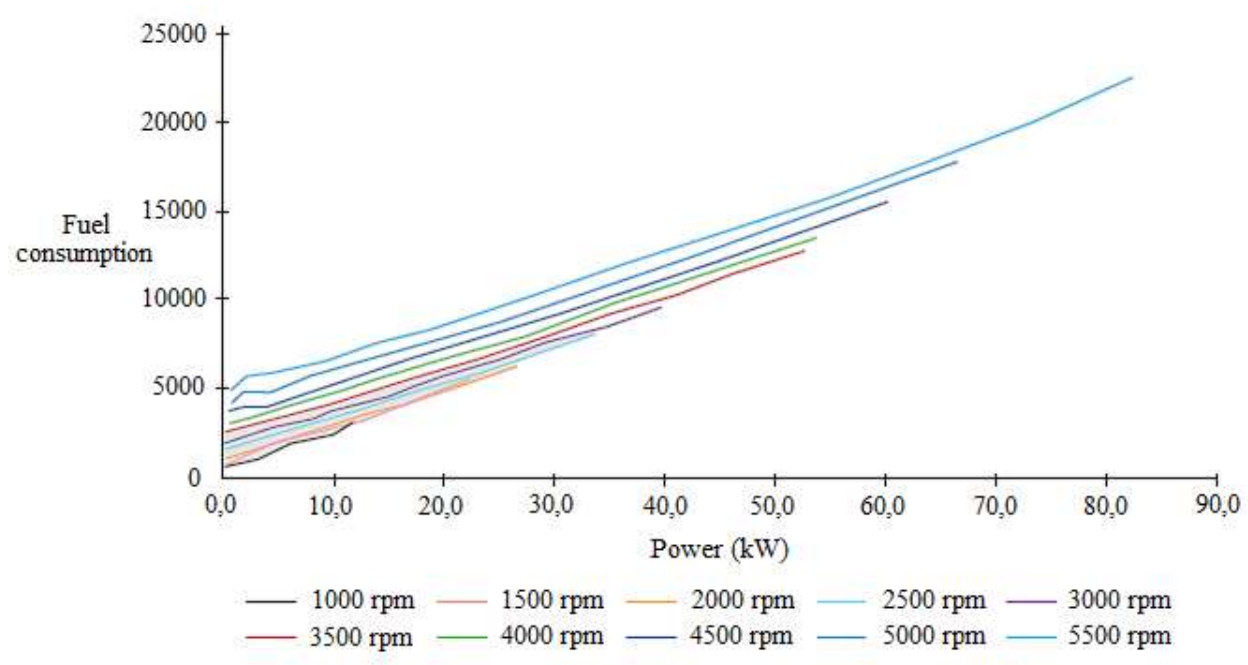

Figure 9. Lines of Willans

\subsection{RICE-generator set model}

In the literature there are various models of the dynamic behavior of the speed of a RICE [32]-[36]. In [34] propose a simple second-order system that considers the spark advance, the valve openings, and the load torque as input variables. In [36] present another model that for its simplicity has been chosen as a starting point for this work. To consider the physical phenomena described above, the model has been modified to include the valve point, the HHV of the gas and the gas flow as input variables as shown in Figure 10 .

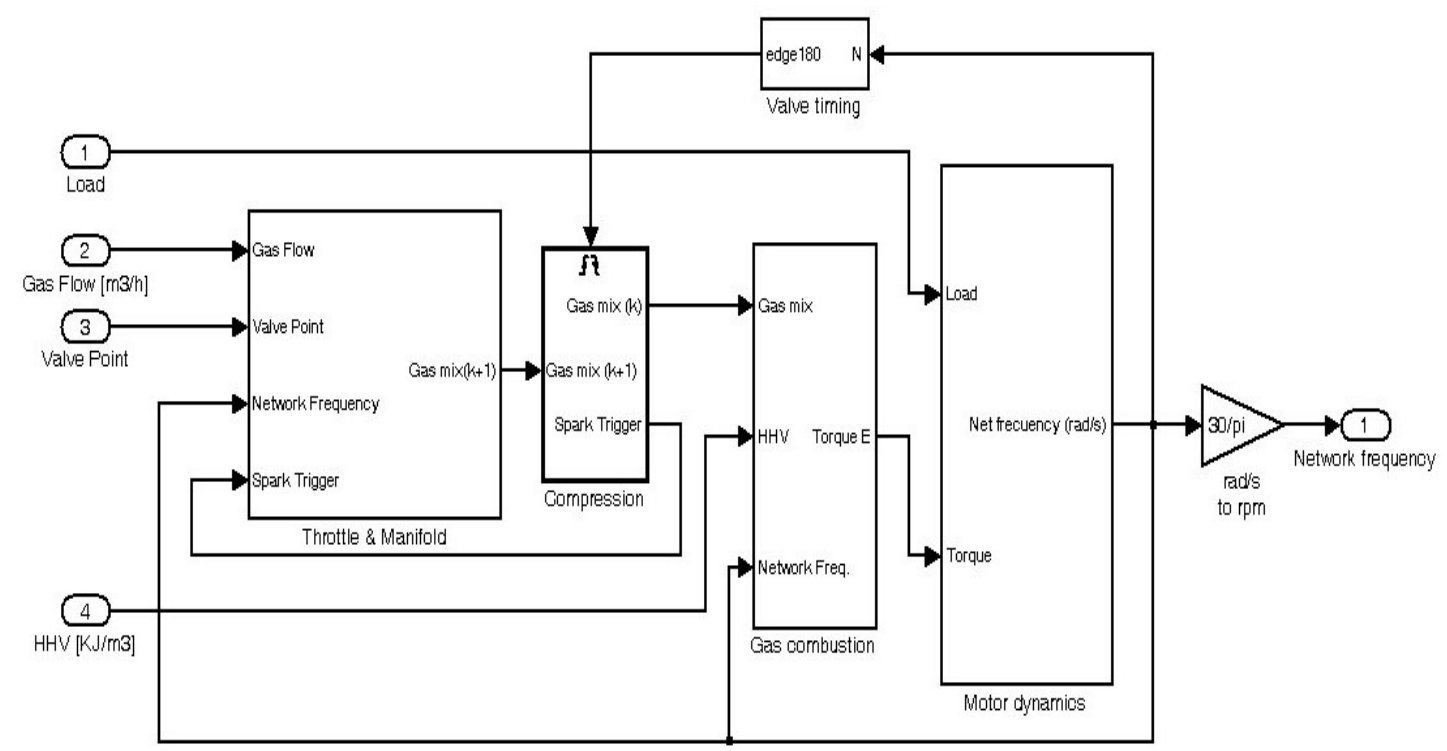

Figure 10. Proposed RICE model

The accelerator has been modelled as a gas injection which depends of two variables: the valve opening point and the pressure at the inlet (5), (6) and (7).

$$
\begin{aligned}
& m_{m}=f(\theta) g\left(P_{m}\right) \\
& f(\theta)=\left[2.82-0.052 \theta+0.103 \theta^{2}-0.0006 \theta^{3}\right][0.025 m g-0.25]
\end{aligned}
$$




$$
g\left(P_{m}\right)=\left\{\begin{array}{cl}
1 \quad P_{m \leq} & \frac{P_{a m b}}{2} \\
\frac{2}{P_{a m b}} \sqrt{P_{m} P_{a m b}-P_{m}^{2}} & \frac{P_{a m b}}{2} \leq P_{m} \leq P_{a m b} \\
-\frac{2}{P_{a m b}} \sqrt{P_{m} P_{a m b}-P_{a m b}^{2}} & P_{a m b} \leq P_{m} \leq 2 P_{a m b} \\
-1 \quad P_{m} & \geq 2 P_{a m b}
\end{array}\right.
$$

where: $\mathrm{m}_{\mathrm{m}}$ is the gas mix flow rate into the manifold $(\mathrm{g} / \mathrm{s}) ; \theta$ is the valve point $(\mathrm{deg}) ; \mathrm{P}_{\mathrm{m}}$ is the manifold pressure (bar) and $\mathrm{P}_{\mathrm{amb}}$ is the atmospheric pressure (bar).

The gas pressure at the inlet is modelled as a differential equation in which the difference between the gas flow reaching the inlet and the amount of gas entering the cylinder govern the change in the amount of gas mass with respect to time. Variation of mass with respect to time in accordance with the law of ideal gas is proportional to the time derivative of the pressure at the inlet. In addition, the amount of fuel mass entering the cylinder is a function of pressure at the inlet and the engine speed.

As this model is for a four-stroke engine with four cylinders in line, the intake, compression, combustion and exhaust occur simultaneously in each of the four cylinders. The torque generated is modelled from an empirical equation given by [36], which relates the mass of air charged into the cylinder, the gas/air ratio, spark advance, engine speed and the HHV of the gas mix (8).

$T_{E}=\left[-181.3+379.36 m_{m}+21.91(A / F)-0.85(A / F)^{2}+0.26 \sigma-0.0028 \sigma^{2}+0.027 N-\right.$ $\left.0.000107 N^{2}+0.00048 N \sigma+2.55 \sigma m_{m}-0.05 \sigma^{2} m_{m}\right][0.00025 H H V]$

where: $\mathrm{m}_{\mathrm{m}}$ is the gas mix flow rate in the cylinder $(\mathrm{g}) ; \mathrm{A} / \mathrm{F}$ is the air to gas ratio; $\sigma$ is the spark advance (degrees before top- dead- center); $\mathrm{T}_{\mathrm{E}}$ is the torque produced by the engine $(\mathrm{Nm})$ and $\mathrm{N}$ is the engine speed $(\mathrm{rad} / \mathrm{s})$

Once the torque generated by the engine is known, acceleration is obtained by the resistance torque and rotational inertia engine by (9).

$$
J \cdot \dot{N}=T_{E}-T_{L}
$$

Where: $\mathrm{J}$ is the engine rotational moment of inertia $\left(\mathrm{kg} \cdot \mathrm{m}^{2}\right) ; \dot{\mathrm{N}}$ is the engine acceleration $\left(\mathrm{rad} / \mathrm{s}^{2}\right)$ and $\mathrm{T}_{\mathrm{L}}$ is the torque produced by the load $(\mathrm{Nm})$.

The generator is a synchronous machine whose speed of rotation $(\mathrm{N})$ is rigidly linked to the frequency of the power generation according to (10).

$$
N=\frac{60 f}{p}
$$

Where $p$ is the number of pole pairs of the machine [37]. Therefore, voltage frequency is defined by the RICE-engine speed.

\subsection{Proposed control strategy}

A frequency cascade control of the blower frequency and the valve point in the manifold has been chosen using the global physical modelling of the system described in previous sections as shown in Figure 11. Cascade control architecture is used to maximize the benefits by decreasing the energy of the control actions and increasing the speed of response [38].

The PID1 controller obtains the blower frequency from the speed error of the RICE. The PID2 obtains the valve point from the blower frequency error. This control acts in a steady state by opening the valve. As a result, the blower frequency is constant in steady state and this is desirable because this means a constant flow of air into the gasifier and so the gasifier operates at a constant operating point. Constant pressure regulation using a mechanical valve ensures that the flow of gas leaving the gasifier is constant regardless of the subsequent reduction of flow due the valve point. 


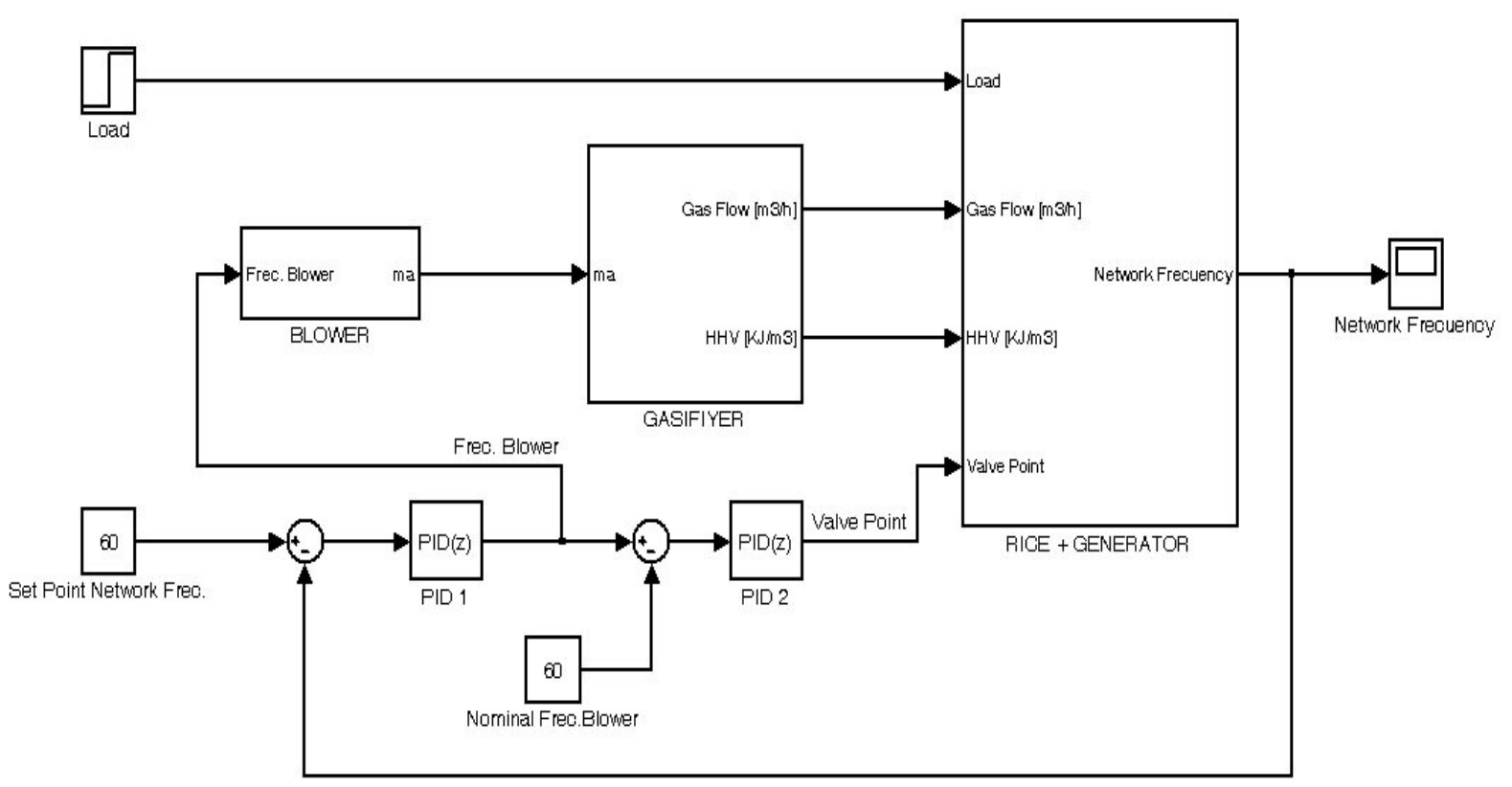

Figure 11. Control architecture block diagram

\section{RESULTS AND DISCUSSION}

By using Matlab-Simulink was possible to simulate the time response of the modelled system under open loop and closed loop control architecture. Because the model is reasonably similar to the real system as shown in Figure 12, we have calculated the values of the drivers and tested the model in a closed loop.

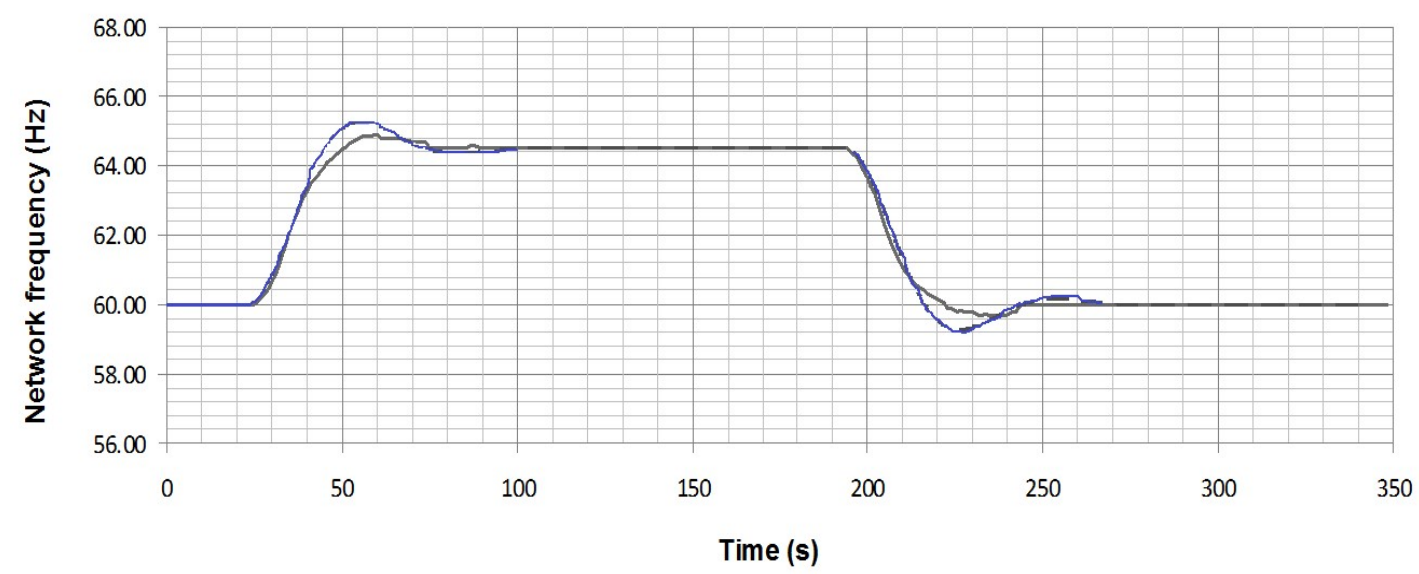

Figure 12. Model and real system open loop response

A cascade control was designed to control the frequency of the rural microgrid so that overshoot and settling time were minimized. In steady state, the valve point is different for each level of load and the blower frequency is set at the nominal point that improves the stability of the gasifier. It can be seen in Figure 13 that the model is stable in closed loop, and the network frequency and blower frequency are controlled. The air flow into the gasifier is controlled by the valve point. A $10 \mathrm{~kW}$ slope on the load requires 120 seconds to stabilize completely. 

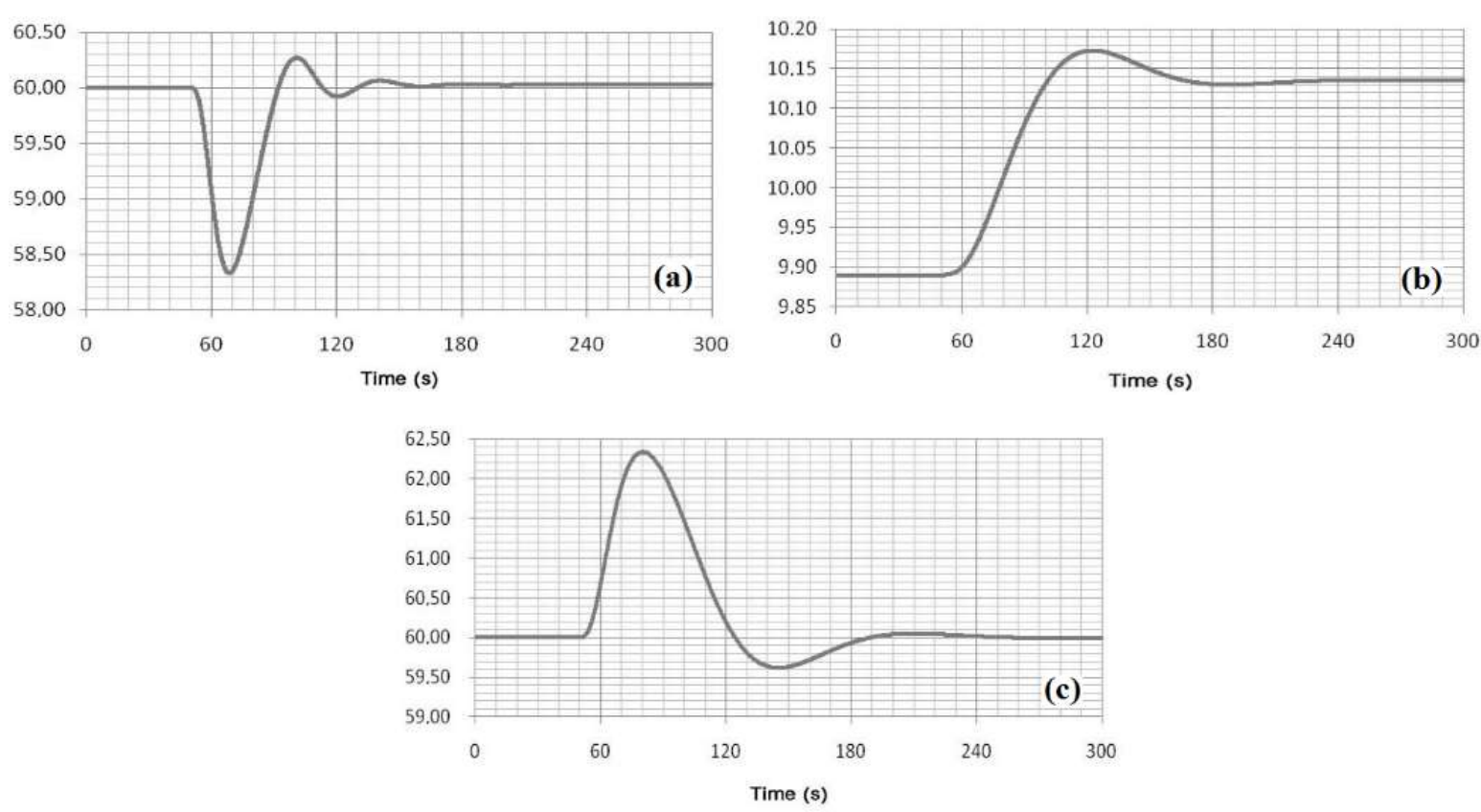

Figure 13. Model closed loop response: (a) Network frequency (Hz), (b) Valve point (\%),

(c) Blower frequency $(\mathrm{Hz})$

\section{CONCLUSION}

Gasification of biomass is projected as one of the best power generation options to supply energy to isolated areas in developing countries. Adequate frequency control of the voltage supplied by these systems is desirable. An accurate model of the system is necessary to design a reliable control. This paper presents a physical model of all the parts of the system: gasifier, blower, RICE and generator, while taking into account nonlinearities and the dynamic behavior of the production of gas from a biomass gasifier. A global analysis has been performed using previous contributions, experimental data and simulations.

In this paper the operation of a downdraft gasifier is analyzed in detail and we obtain the transfer function that governs operation. Gasification is a process with significant instabilities because of the heterogeneity of the internal environment and the heterogeneity of the wood for burning. Calorific value and the flow of the gas generated by the gasifier are modelled. Furthermore, a RICE model has been adapted to include the gas generated by the gasifier as input. The global model is developed in Matlab-Simulink based on a real downdraft gasifier installed in Necoclí (Colombia) where the model has been validated by analyzing the open loop response.

Finally, a cascade control is proposed to control the frequency of the rural microgrid, so that overshoot and settling time are minimized. With this control architecture, the valve point is different for each level of load and the blower frequency is at the nominal point that improves the stability of the gasifier in steady state.

\section{ACKNOWLEDGEMENTS}

This research work has been possible with the support of the Instituto de Planificación de Soluciones Energéticas de Colombia IPSE, and through the support of the Institute for Energy Engineering of the Universidad Politécnica de Valencia.

\section{REFERENCES}

[1] Umar U, Firdaus F, Soeprijanto A, Penangsang O. "Optimal Expenditure and Benefit Cost Based Location, Size and Type of Dgs in Microgrids Systems Using Adaptive Real Coded Genetic Algorithm," TELKOMNIKA (Telecommunication, Computing, Electronics and Control), 16(1): 10-17, 2018.

[2] Zhu J, Pan W X. "Intelligent Control of Wind/Photovoltaic Microgrid Information Fusion," TELKOMNIKA (Telecommunication, Computing, Electronics and Control). 15(1): 264-272, 2017.

[3] Ospino A, Muñoz Y. "Evaluation of Hybrid System of Renewable Electricity Generation for A Remote Area of Colombia Using Homer Software," Tecciencia. 9: 57-67, 2014. 
[4] Adefarati T, Bansal R C. "Integration of Renewable Distributed Generators into the Distribution System: A Review," IET Renewable Power Generation. 10(7): 873-884, 2016.

[5] Saxena A, Chandra S. "Rural Electrification in India using Distributed Generation: Current Scenario. Government Initiatives, Regulatory \& Technical Issues," American International Journal of Research in Science, Technology. 1: 76-81, 2013.

[6] Sen R, Bhattacharyya S C. "Off-grid Electricity Generation with Renewable Energy Technologies in India: An Application of HOMER," Renewable Energy. 62: 388-398, 2014.

[7] Nikolovski S, Vukobratović M, Majdandžić L. "Protection Coordination and Anti Islanding Protection Solution for Biomass Power Plant Connected on Distribution Network," International Journal of Electrical and Computer Engineering. 6(6): 2526-2537, 2016.

[8] Siemons R. "Identifying a Role for Biomass Gasification in Rural Electrification in Developing Countries: The Economic Perspective" Biomass \& Bioenergy. 20: 271-285, 2001

[9] Kohli S, Ravi M R. "Biomass Gasification for Rural Electrification: Prospects and Challenges," SESI Journal. 13: 83-101, 2003.

[10] Ueasin N, Wongchai A, Nonthapot S N. "Performance Assessment and Optimization of Biomass Steam Turbine Power Plants by Data Envelopment Analysis," International Journal of Energy Economics and Policy. 5(3): 668$672,2015$.

[11] Paez A F, Maldonado Y M, Castro A O. "Future Scenarios and Trends of Energy Demand in Colombia using Long-range Energy Alternative Planning," International Journal of Energy Economics and Policy. 7(5): 178-190, 2017.

[12] Algarín C R, Llanos A P, Castro A O. "An Analytic Hierarchy Process Based Approach for Evaluating Renewable Energy Sources," International Journal of Energy Economics and Policy. 7(4): 38-47, 2017.

[13] Buragohain B, Mahanta P, Moholkar V S. "Biomass Gasification for Decentralized Power Generation: The Indian Perspective," Renewable and sustainable Energy Reviews. 14: 73-92, 2010.

[14] Robles-Algarín C A, Taborda-Giraldo J A, Ospino-Castro A J. "Procedimiento para la Selección de Criterios en la Planificación Energética de Zonas Rurales Colombianas," Informacion Tecnologica. 29(3): 71-80, 2018.

[15] Kumar B, Bhongade S. "Load Disturbance Rejection based PID Controller for Frequency Regulation of a Microgrid," Indonesian Journal of Electrical Engineering and Computer Science. 7(3): 625-642, 2017.

[16] Morren J, De Haan S W H, Ferreira J A. "Contribution of DG Units to Primary Frequency Control," European Transactions on Electrical Power. 2006; 16(5): 507-521.

[17] Anderson P M, Fouad A. "Power System Control and Stability," New York City, United States: Wiley-IEEE Press, 2008.

[18] Kundur P. "Power System Stability and Control," New York, United States: Mc Graw-Hill Pres, 1994.

[19] Segura-Heras I, Escrivá-Escrivá G, Alcázar-Ortega M. "Wind Farm Electrical Power Production Model for Load Flow Analysis," Renewable Energy. 36: 1008-1013, 2011.

[20] Morren J, Pierik J T G, De Haan S W H. “Voltage Dip Ride-Through Control of Direct-Drive Wind Turbines," 39th International Universities Power Engineering Conference. Bristol; United Kingdom. 3: 934-938, 2004.

[21] Zhu Y, Tomsovic K. "Development of Models for Analyzing The Load-Following Performance of Microturbines and Fuel Cells," Electrical power Systems Research. 62: 1-11, 2002.

[22] Centeno F, Mahkamov K, Silva Lora E, Andrade R V. "Theoretical and Experimental Investigations of A Downdraft Biomass Gasifier-Spark Ignition Engine Power System," Renewable energy. 37: 97-108, 2012.

[23] Sheth P N, Babu B V. "Experimental Studies on Producer Gas Generation From Wood Waste in A Downdraft Biomass Gasifier," Bioresource Technology. 100: 3127-3133, 2009.

[24] Tinaut F V, Melgar A, Pérez J F, Horrillo A. "Effect of Biomass Particle Size and Air Superficial Velocity on the Gasification Process in A Downdraft Fixed Bed Gasifier" Fuel processing Technology. 89: 1076-1089, 2008.

[25] Henriksen U, Ahrenfeldt J, Jensen T K, Hindsgaul C, Sørensen L H. "The Design, Construction and Operation of a 75 kW Two-Stage Gasifier," Energy. 31: 1542-1553, 2006.

[26] Díaz C J. "Understanding Biomass Pyrolysis Kinetics: Improved Modelling Based on Comprehensive Thermokinetic Analysis," P. Eng. Thesis, Polytechnic Univ. of Catalonia, Barcelona, 2006.

[27] Di Blasi C. "Modeling Chemical and Physical Processes of Wood and Biomass Pyrolysis," Progress in Energy and Combustion Science. 34: 47- 90, 2008.

[28] Di Blasi C. "Combustion and Gasification Rates of Lignocellulosic Chars," Progress in Energy and Combustion Science. 35: 121-140, 2009.

[29] Na J I, Park S J, Kim Y K, Lee J G, Kim J H. "Characteristics of Oxygen-Blown Gasification for Combustible Waste in A Fixed-Bed Gasifier," Applied Energy. 75: 275-285, 2003.

[30] Sharma, A K. "Experimental Study on $75 \mathrm{~kW}$ Downdraft (Biomass) Gasifier System," Renewable Energy. 34 : 1726-1733, 2009.

[31] Zainal Z A, Rifau A, Quadir G A, Seetharamu K N. "Experimental Investigation of A Downdraft Biomass Gasifier," Biomass \& Bioenergy. 23: 283-289, 2002.

[32] Galgano A, Salatino P, Crescitelli S, Scala F, "Maffettone P L. A Model of the Dynamics of a Fluidized Bed Combustor Burning Biomass," Combustion and Flame. 140: 371-384, 2005.

[33] Banapurmath N R, Tewari P G, Yaliwal V S, Kambalimath S, Basavarajappa Y H. "Combustion Characteristics of A 4-Stroke CI Engine Operated on Honge Oil, Neem And Rice Bran Oils When Directly Injected and Dual Fuelled with Producer Gas Induction," Renewable Energy. 34: 1877-1884, 2009. 
[34] Hrovat D, Sun J. "Models and Control Methodologies for IC Engine Idle Speed Control Design," Control Engineering Practice. 5: 1093-1100, 1997.

[35] Crossley P R, Cook J. "A Nonlinear Engine Model for Drive Train System Development," IEEE International Conference Control '91. London, England. 921-925: 25-28, 1991.

[36] Mora J F. “Máquinas eléctricas,” Madrid, España: Mc Graw-Hill/Interamericana Press, 2008.

[37] Howell M N, Best M C. "On-line PID Tuning for Engine Idle-Speed Control Using Continuous Action Reinforcement Learning," Control Engineering Practice. 8: 147-154, 2000.

[38] Paes T. Modelling for control of a biomass gasifier. Eindhoven Univ. of Technology, Eindhoven, acad. papers, Nederland. 20-40, 2005. 